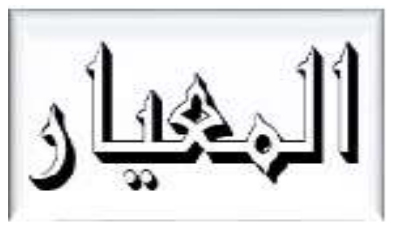

Al Mi'yar

Vol. 3, No. 1, April 2020

P-ISSN: 2620-6749, E-ISSN: 2620-6536

DOI: $10.35931 / a m . v 3 i 1.205$

Disetujui: 10-04-2020

\title{
KUALITAS HASIL TERJEMAHAN GOOGLE TRANSLATE DARI BAHASA ARAB KE BAHASA INDONESIA
}

\author{
Hidayatul Khoiriyah \\ Universitas Islam Negeri Sunan Kalijaga Yogyakarta, Indonesia \\ Email: hidakhoir3@gmail.com
}

\section{Abstract}

The development of technology has a big impact on human life. The existence of a machine translation is the result of technological advancements that aim to facilitate humans in translating one language into another. The focus of this research is to examine the quality of the google translate machine in terms of vocabulary accuracy, clarity, and reasonableness of meaning. Data of mufradāt taken from several Arabic translation dictionaries, while the text is taken from the phenomenal work of Dr. Aidh Qorni in the book Lā Tahzan. The method used in this research is the translation critic method.

The results showed that in terms of the accuracy of vocabulary and terms, Google Translate has a good translation quality. In terms of clarity and reasonableness of meaning, google translate has not been able to transmit ideas from the source language well into the target language. Furthermore, in grammatical, the results of the google translate translation do not have a grammatical arrangement, the results of the google translate translation do not have a good grammatical structure and are by following the rules that applied in the target Indonesian language.

From the data, it shows that google translate should not be used as a basis for translating an Arabic text into Indonesian, especially in translating verses of the Qur'ān and Hadits. A beginner translator should prefer a dictionary rather than using google translate to effort and improve the ability to translate.

Key Words : Translation, Google Translate, Arabic

\section{PENDAHULUAN}

Kehidupan serba digital di era globalisasi ini memaksa manusia harus bersinggungan dengan bahasa asing, kontak antar bahasa terjadi antara satu 
Hidayatul Khoiriyah: Kualitas Hasil Terjemahan Google Translate Dari Bahasa Arab ke Bahasa Indonesia

bangsa dengan bangsa lainnya. Hal tersebut memicu terjadinya kontak budaya antara keduanya. ${ }^{1}$

Menurut Weinrich dalam Ruskhan, pengaruh bahasa asing terhadap bahasa tertentu merupakan perwujudan dari difusi dan akulturasi budaya. Dampaknya terlihat dalam bentuk penyerapan sebuah kosakata bahasa tertentu. ${ }^{2}$ Penerjemahan antar bahasa menjadi cara untuk menemukan jalan keluar dalam persinggungan dua bahasa atau lebih. Penerjemahan merupakan proses komunikasi dengan melibatkan dua bahasa yang berbeda. Tujuan akhir kegiatan penerjemahan adalah tercapainya kesepahaman makna dan pesan antara pengirim dan penerima pesan, sehingga antar pemilik bahasa dapat memiliki kesepahaman makna dan informasi. ${ }^{3}$

Pada zaman sekarang ini, penerjemahan memiliki peranan yang sangat penting, khususnya di dalam dunia akademik yang banyak menggunakan literatur-literatur berbahasa asing ${ }^{4}$, misalnya bahasa Arab yang sering menjadi kendala bagi para akademisi yang memiliki pemahaman bahasa Arab yang kurang bagus. Oleh karena itu, salah satu aplikasi dari penerjemahan dengan memanfaatkan teknologi adalah dengan pemakaian google translate atau mesin penerjemahan dengan aplikasi google yang bisa digunakan untuk mengalihkan pesan dari bahasa asing ke dalam bahasa Indonesia.

Pernyataan senada juga disampaikan oleh Asmaul Fauziah dkk, bahwasanya akurasi makna google translate dalam kitab "Fathul Qorib" tidaklah akurat. Sebab, google translate hanya tepat dalam menerjemahkan makna isim, fi'il, dan huruf secara harfiah, bukan dalam sebuah kalimat yang sempurna. Selain itu, hasil terjemahan google translate pada makna khusus, istilah bidang keagamaan, ejaan, tanda baca, tata kalimat, morfologi, dan

${ }^{1}$ Rika Astari dan Samsul Hadi, "Pengaruh Budaya Terhadap Istilah Sains dan Teknologi dalam Bahasa Arab," Adabiyyāt: Jurnal Bahasa dan Sastra 13, no. 2 (31 Desember 2014): h. 254.

${ }^{2}$ Abdul Gaffar Ruskhan, Bahasa Arab dalam Bahasa Indonesia: Kajian tentang Pemungutan Bahasa (Jakarta: Gramedia Widiasarana Indonesia, 2007), h. 1.

${ }^{3}$ Teguh Setiawan, "Korpus Dalam Kajian Penerjemahan," 2017, h. 1.

4 Tri Pujiati, "Pemanfaatan Google Translate Dalam Penerjemahan Teks Bahasa Inggris Ke Dalam Bahasa Indonesia (Aplikasi Linguistik Terapan Bidang Penerjemahan)," 2017, h. 129. 
Hidayatul Khoiriyah: Kualitas Hasil Terjemahan Google Translate Dari Bahasa Arab ke Bahasa Indonesia

leksikon tidak akurat. Sehingga, makna terjemahan yang dihasilkan tidak tepat, dan pesan yang terkandung di dalamnya tidak dapat dipahami. ${ }^{5}$

Layanan mesin google translate digunakan sebagai objek dalam penulisan makalah ini karena layanan mesin ini sering digunakan oleh para mahasiswa ataupun penerjemah untuk menerjemahkan secara instan. Kendala yang dialami oleh pengguna layanan ini adalah sering ditemukan terjemahan yang tidak gramatikal. ${ }^{6}$

Oleh karena itu, penulis ingin mengetahui sejauh mana kesalahan mesin google translate dalam menerjemahkan teks bahasa Arab ke bahasa Indonesia.

\section{METODE PENELITIAN}

Penelitian ini bertujuan untuk melihat kualitas hasil terjemahan mesin terjemah google translate dalam menerjemahkan bahasa Arab ke bahasa Indonesia. Penelitian ini termasuk pada penelitian tentang terjemahan. Penelitian ini mengambil model penelitian tentang proses penerjemahan dan hasil terjemahan dengan cara melihat proses penerjemahan dari bahasa Arab ke bahasa Indonesia melalui google translate dan mengevaluasi hasil terjemahannya.

Data utama dalam penelitian ini adalah teks-teks bahasa Arab yang diambil dari buku Lā Tahzan karangan Dr. Qaidh Al-Qorni dan kamus istilah Arab-Indonesia. Guna perbandingan dan juga mempermudah dalam penelitian, penulis juga menggunakan buku terjemahan Lā Tahzan dari penerbit Qisty Press ${ }^{7}$ yang telah beredar di pasaran untuk membandingkan hasil terjemahan google translate dengan teks terjemahan Indonesia.

Kata-kata ataupun kalimat dalam bahasa Arab tentunya sangat berbeda dengan bahasa Indonesia. Cara untuk menentukan kalimat ataupun kosa kata bahasa Arab digunakan sistem purposive sampling, yaitu menentukan kalimat

${ }^{5}$ Asmaul Fauziyah, Irhamni, dan Ali Ma'sum, Akurasi Hasil Terjemahan Bahasa Arab ke dalam Bahasa Indonesia dengan Aplikasi “Google Translate” (Malang: UM Malang, 2012), h. 15.

6 Zaimatus Sa'diyah, "Tipologi Kesalahan Kebahasaan Dan Keakuratan Hasil Terjemahan Google Translate Teks Bahasa Indonesia Ke Dalam Bahasa Arab" 6, no. 2 (2014): h. 4.

${ }^{7}$ Buku Lā Tahzan terbitan Qisty Press diterjemahkan oleh Samson Rahman, penyunting, Syamsuddin TU dan Anis Maftukhin, Jakarta: Qisthi Press, 2004. xxviii +572 hal; $15 x 24 \mathrm{~cm}$, cetakan pertama September 2003 dan cetakan ke-18 Maret 2005. 
Hidayatul Khoiriyah: Kualitas Hasil Terjemahan Google Translate Dari Bahasa Arab ke Bahasa Indonesia

ataupun kosa kata yang cocok dan sesuai dengan kebutuhan penelitian. Dalam pengumpulan data, penulis menempuh langkah-langkah berikut: pertama, menentukan kosa kata dan istilah bahasa Arab baik berupa kata benda maupun kata kerja yang akan diterjemahkan melalui google translate. Kosa kata dan peristilahan diambil dari kamus istilah bahasa Arab-Indonesia. Kedua, memilih dan mengambil bacaan teks bahasa sumber yang telah ditentukan dari buku sampel. Ketiga, mencari terjemahan bahasa Indonesia (kosa kata, istilah dan bacaan) dari kamus dan buku terjemahan.

Dalam menganalisis data, penulis berpegang pada sistematika kritik terjemah atau juga biasa disebut dengan penelitian kualitas terjemahan. Ada beberapa tahap dalam melakukan analisis data dalam penelitian ini, pertama, menerjemahkan teks bahasa Arab yang telah dipilih melalui mesin google translate. Kedua, memberikan perbandingan hasil terjemahan google dengan terjemahan manusia yaitu kamus untuk kosa kata, dan istilah; buku terjemahan sampel yang telah diterbitkan untuk teks bahasa sumber. Ketiga, menganalisis hasil terjemahan google translate dari beberapa kriteria yang telah ditentukan dan juga membandingkannya dengan terjemahan manusia untuk mempermudah proses analisis. Selanjutnya penulis memberikan penilain terhadap hasil terjemahan google translate.

\section{PEMBAHASAN}

\section{A. Terjemahan dan Kriteria Penerjemahan}

\section{Pengertian Terjemah}

Kata terjemah berasal dari bahasa Arab ترجمة yaitu menjelaskan dengan bahasa lain ${ }^{8}$, atau memindahkan makna dari satu bahasa ke bahasa yang lain. Terjemah secara luas diartikan sebagai seluruh kegiatan manusia dalam mengalihkan seperangkat informasi berupa makna maupun pesan (message) baik secara verbal maupun non-verbal

${ }^{8}$ Fr. Louis Ma'luf Al-Yassu'i, Al-Munjid fii al-Lughah wa al-A'lam (Beirut: Dar Al-Masyrik, 1996), h. 60. 
Hidayatul Khoiriyah: Kualitas Hasil Terjemahan Google Translate Dari Bahasa Arab ke Bahasa Indonesia

yang berasal dari bahasa sumber (source information) ke dalam informasi bahasa sasaran (target information). ${ }^{9}$

Dalam narasi lain juga dijelaskan bahwa menerjemah menurut Louis Ma'luf yang dikutip oleh Nur Mufid secara istilah adalah memindahkan atau menyalin gagasan, ide, pikiran, pesan, dan informasi lainnya dari satu bahasa (disebut sumber bahasa) ke dalam bahasa lain (disebut bahasa target). ${ }^{1}$

\section{Macam-macam Terjemah}

Para ahli membedakan terjemahan ke dalam beberapa kategori. Menurut Munip jenis dan ragam terjemahan dapat dikategorikan dalam dua hal, yaitu menurut proses penerjemahan dan jenis naskah yang diterjemahkan. Berdasarkan prosesnya Munip membaginya dalam dua hal yaitu: 1) terjemahan yang berpihak pada teks bahasa sumber, dan 2) terjemahan yang berpihak kepada teks bahasa sasaran. ${ }^{1}$

\section{Kriteria Terjemahan yang Bagus}

Menurut Nababan, kriteria terjemahan yang berkualitas hendaknya meliputi tiga aspek utama, yaitu: aspek keakuratan, aspek keberterimaan dan aspek keterbacaan. Penjelasan ketiga aspek tersebut adalah sebagai berikut:

a. Aspek keakuratan, merupakan istilah yang digunakan untuk mengevaluasi hasil terjemahan, guna melihat apakah teks sumber sudah sepadan dengan teks sasaran. Kemudian akan ditinjau konsep kesepadanan dalam kesamaan pesan yang terdapat dalam kedua teks tersebut. Penerjemahan merupakan pengungkapan kembali pesan dalam bahasa sumber ke dalam bahasa sasaran dengan menggunakan padanan yang terdekat dan wajar.

9 Suhendra Yusuf, Teori Terjemah Pengantar ke Arah Pendekatan Linguistik dan Sosiolinguistik (Bandung: Mandar Maju, 1994), h. 8.

1 Nur Mufid, Buku Pintar Menerjemahkan Arab Indonesia (Surabaya: Pustaka Progressif, 2007), h. 6.

1 Abdul Munip, Strategi dan Kiat Menerjemahkan Teks Bahasa Arab Ke Dalam Bahasa Indonesia (Yogyakarta: Bidang Akademik UIN Sunan Kalijaga, 2008), h. 10. 
Hidayatul Khoiriyah: Kualitas Hasil Terjemahan Google Translate Dari Bahasa Arab ke Bahasa Indonesia

Penerjemahan diartikan sebagai suatu cara pengalihbahasaan menyampaikan makna, pesan, atau amanat yang terkandung dalam bahasa sumber ke dalam bahasa sasaran dengan padanan kata yang memiliki makna serupa sesuai dengan maksud penulisnya agar dapat dipahami oleh pembaca. Ketepatan dalam menerjemahkan sebuah bahasa sumber ke dalam bahasa sasaran membuat pembaca dengan mudah memahami apa yang ingin disampaikan oleh penulis. ${ }^{1}$

b. Aspek keberterimaan, hasil terjemahan merupakan aspek yang merujuk pada padanan kaidah, norma, dan budaya dari bahasa sumber terhadap bahasa sasaran, baik pada tatanan mikro maupun makro. Sebab, sebuah hasil terjemahan yang baik hendaknya tidak bertentangan dengan kaidah-kaidah, norma serta budaya pada bahasa sasaran. Kemampuan penerjemah ini tidak hanya ditunjang oleh penguasaan terhadap bahasa sumber, akan tetapi juga harus memiliki kemampuan dalam memahami budaya dari bahasa sumber dalam menjelaskan ke dalam bahasa sasaran.

c. Aspek keterbacaan, meliputi konteks penerjemahan pada teks sumber dan teks sasaran. Sehingga, hasil terjemahan hendaknya mudah dibaca dan dipahami. ${ }^{1}$

Berdasarkan pada ketiga aspek tersebut, kesimpulan penilaian kualitas suatu naskah terjemahan dapat menggunakan kriteria sebagai berikut:

a) Keakuratan: menyimpang/tidak menyimpang.

b) Kewajaran: wajar/kaku.

c) Keterbacaan bahasa: baku/tidak baku. ${ }^{1}$

1 Husin Husin dan Hatmiati Hątmiati, "Budaya Dalam Penerjemahan Bahasa," Al Mi'yar: Jurnal Ilmiah Pembelajaran Bahasa Arab dan Kebahasaaraban 1, no. 2 (14 Oktober 2018): h. 46-47,

1 Nababan Nuraini dan Sumaßdiono, Penilaian Model Kualitas Terjemahan (Surakarta: Universitas Sebelas Maret, 2012).

1 M. Zaka Al-Farisi, Peđoman Penerjemahan Arab Indonesia (Bandung: Remaja Rosdakarya, 2011), h. 179. 
Hidayatul Khoiriyah: Kualitas Hasil Terjemahan Google Translate Dari Bahasa Arab ke Bahasa Indonesia

\section{Hubungan Bahasa dan Budaya dalam Proses Penerjemahan Arab- Indonesia}

Dalam buku "Penerjemahan Arab-Indonesia antara Bahasa dan Budaya” yang ditulis oleh Hasan secara rinci menjelaskan bagaimana bahasa dan budaya saling berkaitan dan mempengaruhi satu dengan lainnya. ${ }^{1}$ Selain itu, juga ${ }^{5}$ dijabarkan bahwa dalam proses menerjemahkan sebuah teks dari bahasa sumber ke bahasa sasaran juga menuntut kemampuan dari seorang penerjemah untuk memahami kondisi sosial budaya dari suatu masyarakat pemakai bahasa sumber tersebut. Pemahaman seorang penerjemah terhadap kebudayaan bahada sumber ini berperan penting ketika penerjemah menemukan kata, istilah, dan ungkapan atau metafora bahasa yang hanya terdapat dalam bahasa sumber. ${ }^{1}$

Penerjemahan tidak hanya dilakukan kata per kata secara harfiah, tetapi seorang penerjemah yang baik harus memiliki kemampuan mengalihbahasakan bahasa sumber ke dalam bahasa sasaran sesuai dengan kaidah dan makna yang terkandung dalam bahasa sasaran. Selain itu, dalam menerjemahkan sebuah teks, terkadang penerjemah harus pula mengetahui apa yang melatarbelakangi teks tersebut ada. Seorang penerjemah yang baik harus memahami secara utuh dan menyeluruh teks tulisan sekaligus memahami pula sasaran atau pembaca dari teks tersebut untuk memperlancar proses penerjemahan yang dilakukan. ${ }^{1}$

\section{B. Layanan Google Translate}

Mesin pencari Google dalam perkembangannya menyediakan berbagai fasilitas tidak hanya sekedar mencari alamat web. Fasilitas itu antara lain pencarian gambar, video, buku, hasil penelitian, beasiswa dan penerjemah yang disebut Google penerjemah atau Google translate.

1 Hasan Hasan, Penerjemahan ${ }^{5}$ Arab-Indonesia Antara Bahasa dan Budaya (Banjarbaru: Atap Buku, 2017), h. 3.

1 Husin dan Hatmiati, “Budaya Dalam Penerjemahan Bahasa," h. 50.

1 Husin dan Hatmiati, h. 51. 7 
Hidayatul Khoiriyah: Kualitas Hasil Terjemahan Google Translate Dari Bahasa Arab ke Bahasa Indonesia

Fasilitas ini pertama kali dikembangkan oleh Google pada tahun 2007 dengan menggunakan sebuah sistem yang disebut SYSTRAN. ${ }^{1}$

Pemakaian mesin penerjemah Google sangatlah mudah yaitu dengan membuka halaman https://translate.google.co.id maka disana akan tampak muncul kotak yang harus diisi teks yang akan diterjemahkan. Para pengguna tinggal menentukan, teks tersebut akan diterjemahkan dari bahasa sumber tertentu ke dalam bahasa target seperti dalam gambar berikut:

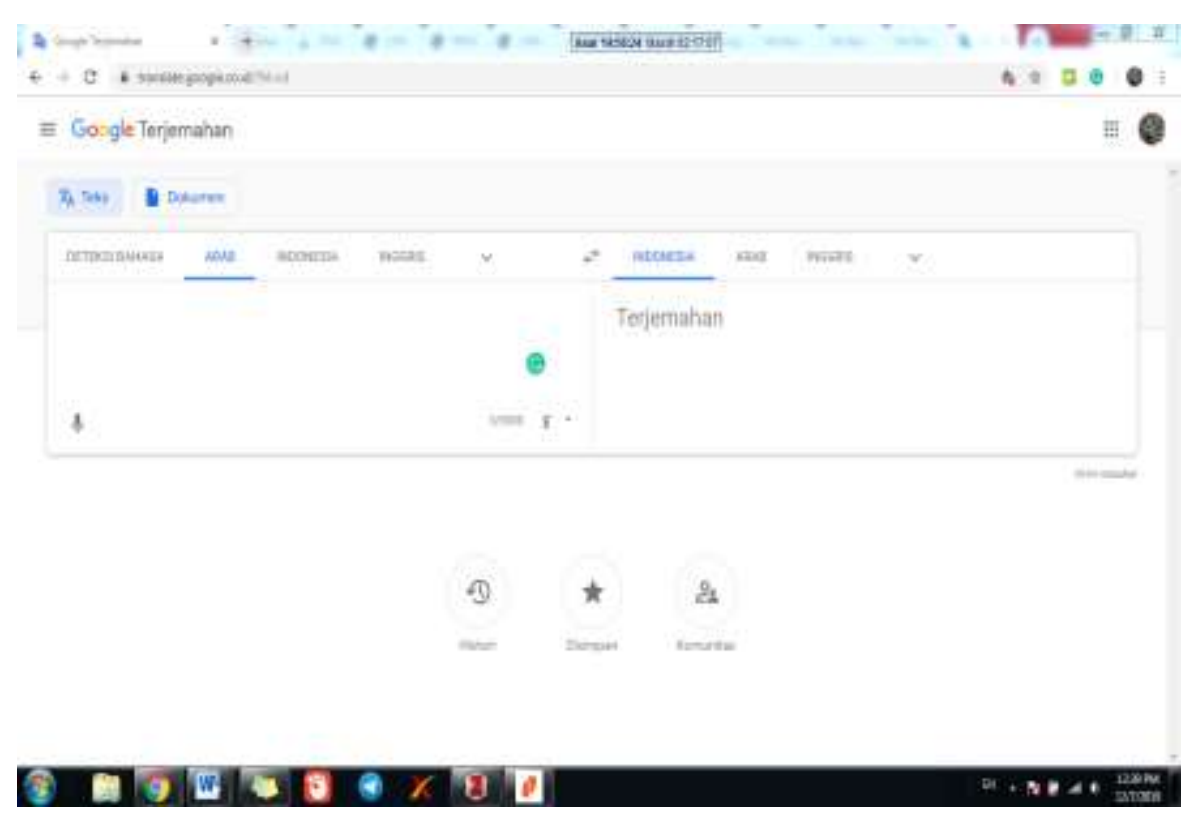

Gambar 1: Kotak Penerjemahan di Mesin Google

\section{Kejelasan dan Kewajaran Makna Terjemahan Google Translate Dari Bahasa Arab Ke Bahasa Indonesia}

Ketidakwajaran suatu teks bacaan akan menimbulkan sebuah problem bagi para pembacanya. Ketidakwajaran dapat terjadi akibat bahasa yang kaku atau pengungkapan yang terlalu berbelit-belit. Pembaca pasti menginginkan suatu bacaan yang berkualitas dalam isi dan mudah dipahami.

1 Novia Arifatun, "Kesalahan Pe̊̊erjemahan Teks Bahasa Indonesia Ke Bahasa Arab Melalui Google Translate (Studi Analisis Sintaksis)," 2012, h. 3. 
Kewajaran suatu bacaan adalah ketika para pembaca merasa enak dan nyaman dalam membaca teks bacaan atau dengan bahasa lain sesuainya susunan terjemahan dengan susunan bahasa para pembaca. Kejelasan hasil terjemahan adalah apabila makna terjemahan bahasa sasaran sesuai dan tidak menyimpang dari makna atau isi bacaan bahasa sumber. Jadi terjemahan yang baik itu adalah terjemahan yang bisa menyampaikan isi, pokok pikiran, gagasan, dan informasi lainnya dari teks bahasa sumber ke dalam bahasa sasaran dan dapat dengan mudah dipahami oleh para pembacanya.

Dalam dunia terjemahan seringkali terjadi berbagai kesalahan dalam menerjemahkan suatu teks atau buku dari bahasa sumber (bahasa Arab) ke bahasa sasaran (bahasa Indonesia). Buku terjemahan yang telah diterbitkan pun dalam penerjemahannya masih terdapat banyak kesalahan di dalamnya. Hal ini menunjukkan bahwa seorang penerjemah masih belum bisa sempurna dalam memproduksi ulang pikiran pengarang dan mentransmisikan makna dari bahasa sumber ke dalam bahasa sasaran. Menjadi masalah yang serius jika terjemahan yang dihasilkan oleh penerjemah melenceng dari maksud dan tujuan teks bahasa sumber.

Mildred L. Larson berpendapat bahwa terjemahan yang baik adalah (1) menggunakan bentuk wajar suatu bacaan, (2) menyampaikan sebanyak mungkin makna yang sama kepada penutur bahasa sasaran, seperti yang dipahami oleh penutur bahasa sumber, dan (3) mempertahankan dinamika teks bahasa sehingga dapat membangkitkan respon pembaca, dan diharapkan sama seperti teks bahasa sumber dalam membangkitkan respon pembacanya. ${ }^{1}$

Dalam pembahasan berikut ini, akan diuraikan analisis terhadap kewajaran dan kejelasan beberapa teks bahasa Arab yang diambil dari buku "Lā Tahzan" karangan Syekh Āidh Al-Qorni. Di samping itu, terjemahan buku Lā Tahzan yang telah beredar di Indonesia hasil terjemahan Samson Rahman juga disertakan dalam analisis kualitas terjemahan makna teks Arab khususnya dalam kejelasan dan kewajaran

1 Munip, Strategi dan Kiat Menêrjemahkan Teks Bahasa Arab Ke Dalam Bahasa Indonesia, h. 28 . 
Hidayatul Khoiriyah: Kualitas Hasil Terjemahan Google Translate Dari Bahasa Arab ke Bahasa Indonesia

sebagai pembanding antara kualitas terjemahan mesin dengan terjemahan manusia.

Berikut merupakan beberapa teks yang dijadikan sampel dalam analisis kewajaran dan kejelasan terjemahan google translate sekaligus teks terjemahan manusia sebagai sebuah perbandingan.

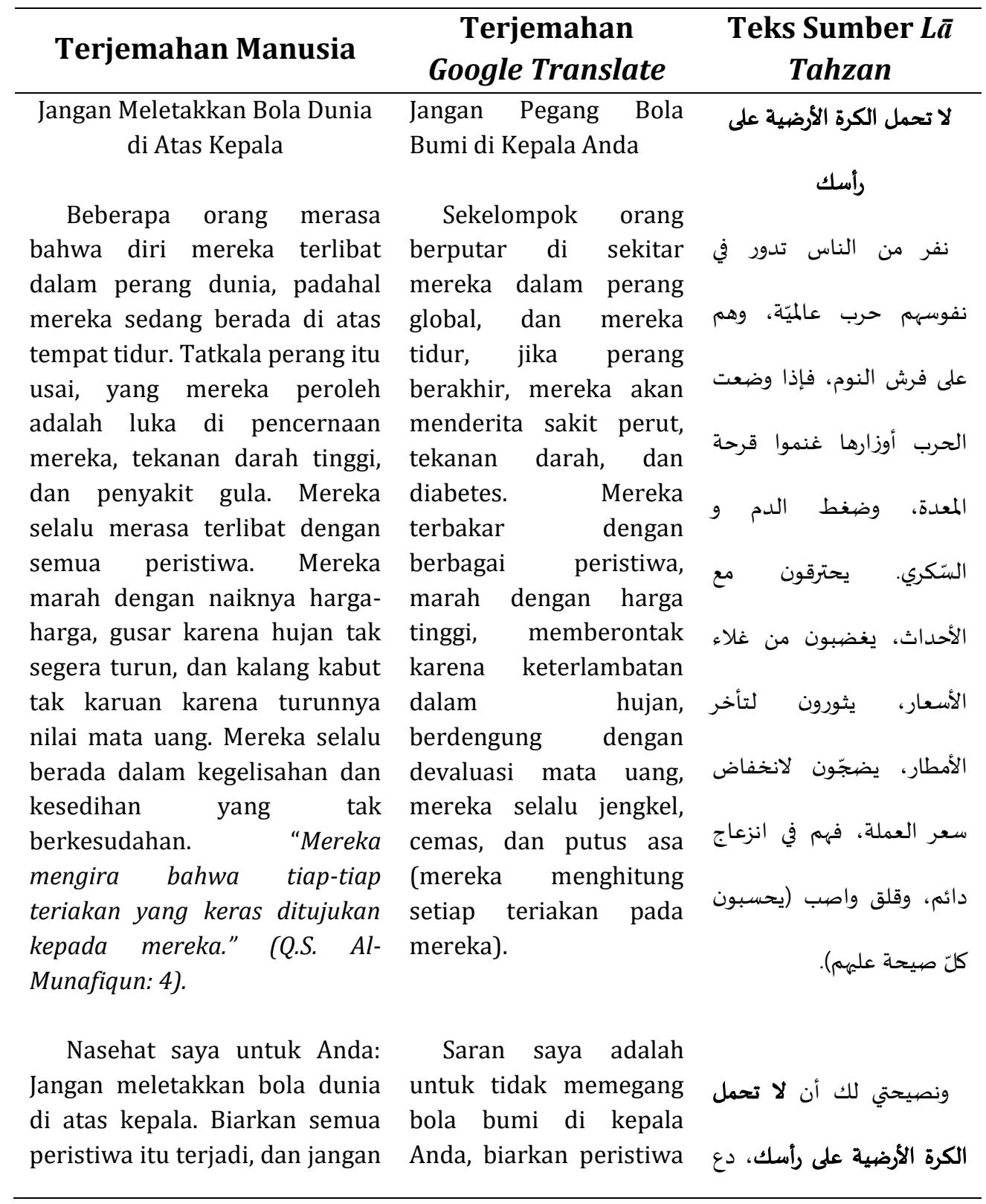




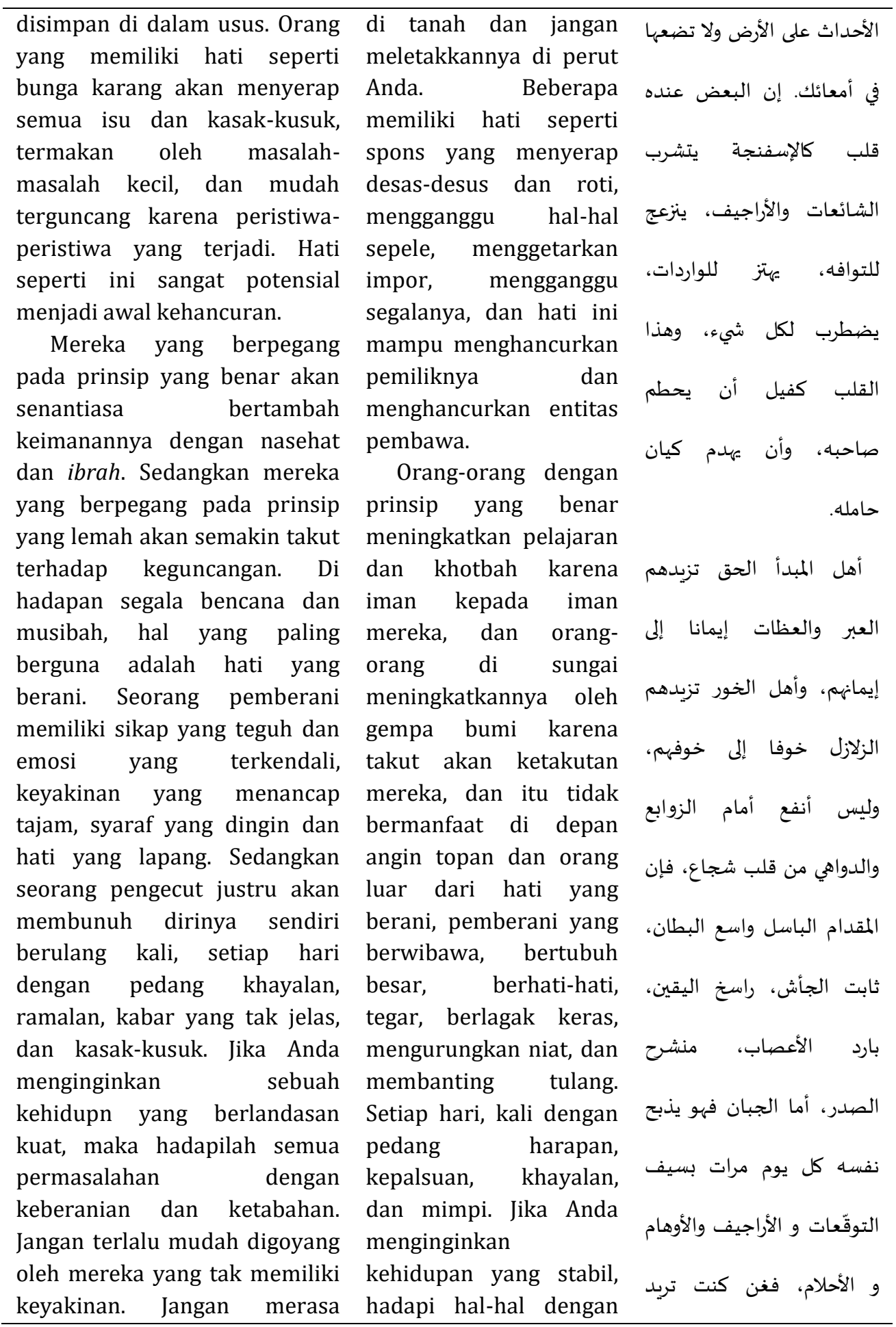




\begin{tabular}{|c|c|c|}
\hline $\begin{array}{l}\text { ebih kuat dari peristiwa itu } \\
\text { endiri, lebih kencang dari } \\
\text { angin puyuh, dan lebih kuat } \\
\text { lari angin topan. Sungguh } \\
\text { xasihan mereka yang memiliki } \\
\text { tati yang lemah, betapa hari- } \\
\text { lari selalu mengguncang } \\
\text { lirinya. "Dan sungguh kamu } \\
\text { kan mendapati mereka, } \\
\text { manusia yang paling lona } \\
\text { repada kehidupan (di dunia)" } \\
\text { Q.S. Al-Baqarah: 96). } \\
\text { edangkan orang-orang yang } \\
\text { nemiliki hati yang kuat } \\
\text { enantiasa mendapatkan } \\
\text { ertolongan dari Allah SWT }\end{array}$ & $\begin{array}{l}\text { keberanian dan cambuk, } \\
\text { dan mereka yang tidak } \\
\text { yakin tidak akan } \\
\text { meremehkan Anda, dan } \\
\text { Anda berada dalam } \\
\text { kesempitan dari apa } \\
\text { yang mereka } \\
\text { rencanakan. Lebih keras } \\
\text { daripada kejadian, dan } \\
\text { lebih kuat dari angin } \\
\text { krisis, lebih kuat dari } \\
\text { angin ribut, lebih kuat } \\
\text { daripada angin ribut } \\
\text { pada orang-orang yang } \\
\text { lemah hati. Berapa hari } \\
\text { Anda goyang (shake) } \\
\text { dan temukan Mereka } \\
\text { tertarik pada kehidupan } \\
\text { orang itu), dan untuk } \\
\text { menjadi ayah, mereka } \\
\text { berasal dari Allah yang } \\
\text { mendukung, dan janji itu } \\
\text { dalam keyakinan } \\
\text { (sehingga } \\
\text { mendatangkan } \\
\text { kedamaian } \\
\text { mereka). }\end{array}$ & الأزمات، وأقوى من الأعاصير، \\
\hline
\end{tabular}

Berdasarkan data di atas, perbedaan antara terjemahan manusia dengan terjemahan google translate sangat jauh berbeda dalam hal kualitas pemilihan diksi bahasa, struktur kalimat, penyampaian isi dan gagasan bahasa sumber. Google translate masih menerjemahkan suatu paragraf secara parsial sehingga menghasilkan suatu terjemahan yang kaku dan saklek. Isi dan gagasan yang terdapat dalam teks sasaran melenceng dari gagasan yang diinginkan oleh pengarang teks bahasa sumber dalam beberapa hal.

Hasil terjemahan google translate dalam bahasa Indonesia dari teks sumber di atas jika dianalisis secara menyeluruh ternyata belum mampu untuk menyampaikan gagasan, isi, dan informasi dari sebuah teks 
Hidayatul Khoiriyah: Kualitas Hasil Terjemahan Google Translate Dari Bahasa Arab ke Bahasa Indonesia

bahasa sumber, belum mampu untuk mencarikan padanan kata yang sesuai dengan makna kata-kata aslinya dan juga belum dapat merefleksikan gaya penerjemahan yang mandiri.

Teks terjemahan manusia memiliki struktur bahasa yang bagus dan sesuai dengan bahasa sasaran. Terjemahan tersebut juga lebih sesuai dengan konteks bacaan bahasa sumber dengan cermat. ${ }^{2}$ Hal ini berbeda jauh dengan terjemahan yangg dihasilkan oleh google translate. Google translate tidak melihat konteks bacaan dari bahasa sumber dan hanya menerjemahkan secara perkata atau peristilah. Walaupun dalam beberapa kalimat sederhana google mampu untuk menerjemahkannya dengan baik.

Penerjemahan bahasa Arab ke bahasa Indonesia harus dimulai dengan pemahaman terlebih dahulu terhadap teks bahasa Arab secara garis besar lalu menerjemahkannya ke dalam bahasa Indonesia setelahnya. Sedangkan google hanya mampu menerjemahkan perkata dalam suatu kalimat bukan menerjemahkannya secara menyeluruh sesuai dengan konteks suatu bacaan.

Untuk para pemula sebaiknya google translate tidak digunakan sebagai acuan dalam menerjemahkan teks bahasa Arab ke bahasa Indonesia, karena selain dari hasil terjemahan yang tidak bagus, google translate juga akan membuat para pemula bergantung pada google translate tersebut. Sehingga ketergantungan terhadap google translate akan menghambat kreativitas mahasiswa atau siswa dalam menerjemahkan bahasa Arab ke dalam bahasa Indonesia.

Jika seseorang berkeinginan untuk menggunakan mesin terjemah google translate maka hasil dari terjemahan itu harus dilakukan proses edit yang serius. Dan melakukan sebuah editing hanya dapat dilakukan oleh orang yang telah mengerti dengan kedua teks bacaan baik dari bahasa sumber maupun bahasa sasaran.

2 Syahabudin Nur, "Problematika Linguistik (Ilmu Al-Lughah) Dalam Penerjemahan Bahasa Arab Ke Bahasa Indonesia," Al Qalam: Jurnal Ilmiah Keagamaan dan Kemasyarakatan, 18 Oktober 2018, h. 49. 
Hidayatul Khoiriyah: Kualitas Hasil Terjemahan Google Translate Dari Bahasa Arab ke Bahasa Indonesia

\section{Gramatika Terjemahan Google Translate dalam Terjemahan Bahasa Sasaran (Bahasa Indonesia)}

Menerjemahkan merupakan suatu proses yang membutuhkan skill tinggi dan keuletan dari seorang penerjemah. Tidak setiap orang mampu untuk terus semangat di dalam dunia penerjemahan. Karena seorang penerjemah dalam tataran ideal hendaknya, pertama, harus memiliki komitmen dan tekad yang kuat untuk bersikap maksimal dalam proses terjemahannya. Kedua, seorang penerjemah harus menjunjung tinggi prinsip kejujuran. Ketiga, penerjemah harus menyadari bahwa pekerjaan menerjemah sampai saat ini belum mendapatkan penghargaan yang tinggi dalam hal materi. Keempat, seorang penerjemah juga harus terbebas atau berupaya membebaskan diri dari pretensi ideologi apapun yang dianutnya.

Dalam pembahasan kali ini, akan dilakukan analisis mengenai hasil terjemahan google dari bahasa Arab ke bahasa Indonesia berkaitan tentang gramatika khususnya gramatika bahasa sasaran (bahasa Indonesia) juga kesalahan-kesalahan dalam penerjemahan teks sumber (bahasa Arab) ke teks bahasa sasaran (bahasa Indonesia) melalui google translate.

Buku Lā Tahzan merupakan kajian serius yang sangat menarik dan dapat dipertanggungjawabkan. Kandungannya dititikberatkan pada berbagai macam problematika yang terjadi dalam kehidupan manusia, yaitu hati yang rentan goyah, cemas, hilang percaya diri, pesimis, bingung, duka, putus asa, terpuruk, dan frustasi. Teks di bawah ini merupakan salah satu teks berbahasa Arab yang diambil dari buku " $L \bar{a}$ Tahzan" karangan Dr. Aidh Al-Qorni yang kandungan teksnya berisikan nasihat supaya kita tidak mudah terpengaruh oleh isu dan desas-desus yang belum pasti kejelasannya. Karena yang demikian sangat berpotensi menjadi awal penyebab suatu kehancuran.

Teks berikut diterjemahkan melalui google translate kemudian hasil terjemahannya akan dianalisis dari berbagai segi khususnya segi pemilihan diksi serta gramatika atau tata bahasa yang sesuai dengan bahasa sasaran yaitu bahasa Indonesia. 
Hidayatul Khoiriyah: Kualitas Hasil Terjemahan Google Translate Dari Bahasa Arab ke Bahasa Indonesia

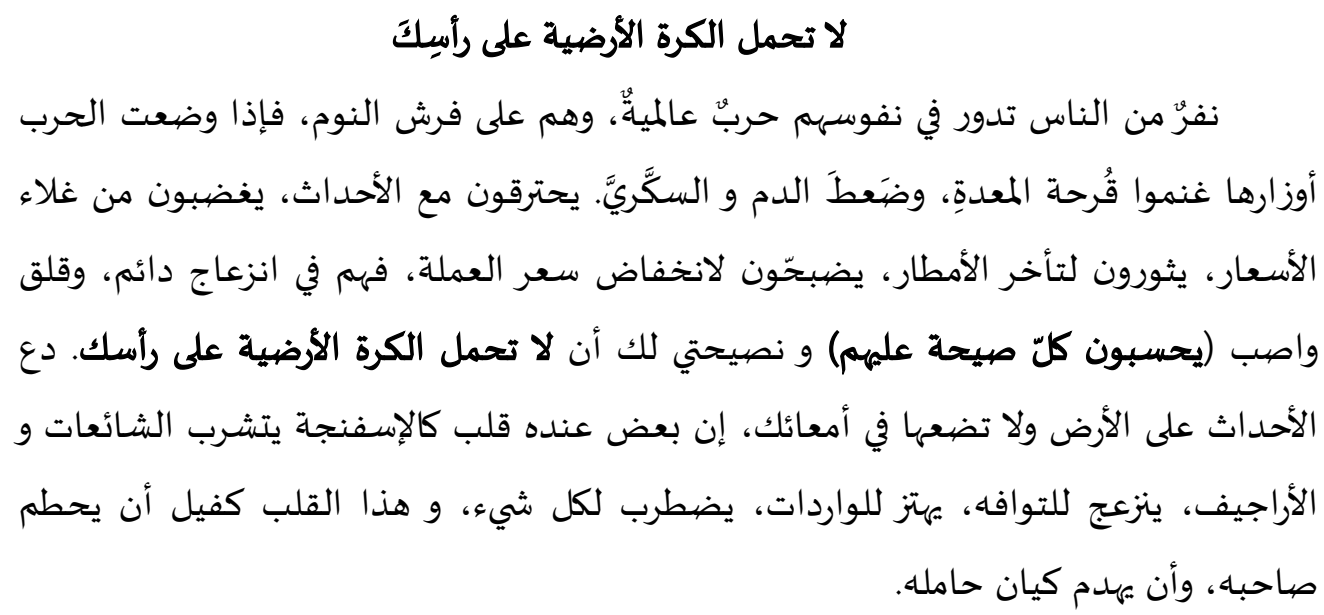

أهل المبدأ الحقّ تزيدهم العبر و العظات إيمانًا إلى إيمانهم، و أهل الخور تزيدهم الزلازل

خوفًا إلى خوفهم، وليس أنفع أمام الزوابع و الواهي من قلبٍ شجاعٍ، فأن المقدام الباسل واسع البطان، ثابت الجأش، راسخ اليقين، بارد الأعصاب، منشرحُ الصدر، أما الجبانُ فهو يذبح فهو يذبح نفسـه كلَّ يوم مرات بسيف التوقّعات و الأراجيفِ والأوهامِ و الأحلامِ، فإن كنت تريد الحياة المستقرَّة فواحه الأمور بشجاعةٍ وجلدٍ، ولايستخفنّك الذين لا يوقنون، ولاتك في ضيقٍ ممّا يمكرون، كن أصلب من الأحداثِ، وأعتى من رياحِ الأزمات، وأقوى من الأعاصير، وارحمتاه لأصحاب القلوب الضعيفة، كم تهزّهم الأيامُ هزًّا (ولتجدنّهم أحرص الناس على حياة)، وأما الأُباةٌ

فهم من الله في مدد، و على الوعد في ثقةٍ (فأنزل الستكينة علههم).

\section{Jangan Pegang Bola Bumi di Kepala Anda}

Sekelompok orang berputar di sekitar mereka dalam perang global, dan mereka tidur di kasur mereka. Jika perang berakhir, mereka memahami sakit perut, tekanan darah dan diabetes. Mereka membakar dengan peristiwa, marah dengan harga tinggi, memberontak karena hujan akhir, pengorbanan untuk devaluasi mata uang, mereka selalu jengkel, cemas dan intimidasi (mereka menghitung setiap teriakan pada mereka) dan saran saya adalah agar Anda tidak memegang bola dunia di kepala Anda. Tinggalkan kejadian di tanah dan jangan taruh di perutmu. Beberapa orang memiliki hati seperti spons yang menyerap desas-desus dan roti, mengganggu hal-hal sepele, menggetarkan impor, mengganggu segalanya, dan hati ini cukup untuk menghancurkan pemiliknya dan menghancurkan entitas pengangkutnya.

Orang-orang dari prinsip yang benar meningkatkan pelajaran dan khotbah dalam iman kepada iman mereka, dan orang-orang di sungai meningkatkan gempa bumi mereka karena takut akan ketakutan mereka, dan itu tidak bermanfaat di depan badai 
Hidayatul Khoiriyah: Kualitas Hasil Terjemahan Google Translate Dari Bahasa Arab ke Bahasa Indonesia

dan yang lemah dari hati yang berani. Dia dibantai, dan dia membantai dirinya sendiri setiap hari dengan pedang harapan, kesombongan, khayalan, dan mimpi. Jika Anda menginginkan kehidupan yang stabil, masalah akan berani dan dicambuk, dan mereka yang tidak yakin tidak akan meremehkan Anda. Dan kasihanilah dia untuk yang lemah hati, Berapa hari mereka gemetar (dan menemukan mereka yang paling bersemangat untuk hidup), dan sebagai ayah mereka berasal dari Tuhan untuk mendukung, dan janji itu dalam kepercayaan (biarkan damai menyertai mereka).

Terjemahan di atas jika kita baca lalu perhatikan, maka terjemahan tersebut hampir tidak bisa dipahami. Dengan begitu terjemahan di atas akan dianalisis kalimat per kalimat untuk memperoleh suatu kebenaran dan atau kesalahan dari terjemahan diatas. Penulis akan mencoba untuk melihat beberapa segi untuk perbaikan terjemahan di atas yaitu dari segi pemilihan diksi kalimat, susunan kalimat dan penambahan ataupun pengurangan kalimat dalam penerjemahan.

\section{لا تحمل الكرة الأرضية على رأسِك}

\section{Jangan Pegang Bola Bumi di Kepala Anda}

Penerjemahan huruf "lā" sebagai āmil jazm diartikan dengan tepat oleh google translate dengan arti "jangan". Pemilihan diksi pegang dan bola bumi kurang tepat karena berhubungan dengan kalimat setelahnya yaitu "di atas kepala anda", hal ini tidak wajar dalam bahasa Indonesia. Diksi yang lebih tepat untuk kalimat "pegang" adalah "meletakkan" dan "bola bumi" adalah "bola dunia". Kata "bola dunia" ini berhubungan dengan bacaan yang berada setelahnya berkaitan dengan permasalahanpermasalahan global yang dihadapi manusia di muka bumi ini. Hakikatnya الكرة الأرضية bermakna globe. Menerjemahkan suatu teks hendaknya diawali dengan membaca dan memahami secara keseluruhan isi teks, kemudian baru menerjemahkannya. Sebagai langkah awal untuk mempelajari terjemahan, para ahli menyarankan agar menerjemahkan teks bahasa Arab secara kalimat per kalimat. Hal ini juga bergantung kepada jenis terjemahan yang dipilih dan disenangi oleh penerjemah. Terjemahan yang lebih tepat untuk judul bacaan diatas adalah "jangan meletakkan bola dunia di atas kepala anda!" 
Hidayatul Khoiriyah: Kualitas Hasil Terjemahan Google Translate Dari Bahasa Arab ke Bahasa Indonesia

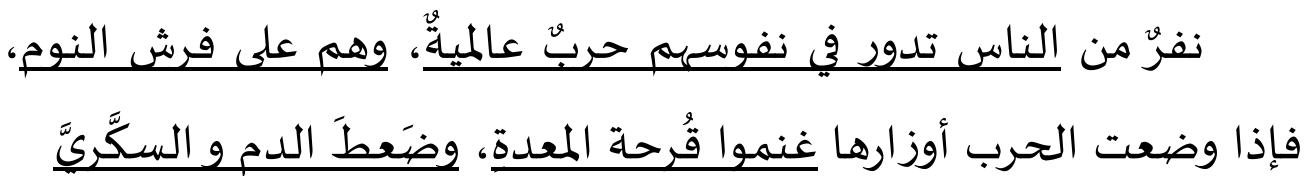

Sekelompok orang dari manusia berputar di sekitar mereka dalam perang global, dan mereka berada di tempat tidur. Jika perang berakhir, mereka memahami sakit perut, tekanan darah dan diabetes.

Huruf “min” dalam kalimat نفر من الناس tidak diterjemahkan secara saklek dengan google translate, hal ini merupakan hal bagus dan menunjukkan bahwa google translate tidak menerjemahkan teks bahasa Arab secara tekstual sebagaimana kamus bahasa. Jika diterjemahkan dengan arti perkata maka terjemahannya akan kurang bagus dan tidak sesuai dengan tatanan bahasa Indonesia, misalnya "orang dari manusia". Terjemahan kalimat تدور في نفوسهم حربٌ عالميّه dengan arti "berputar di sekitar mereka dalam perang global" tidak dapat dipahami secara baik, bahkan merusak pelengkap dari subjek yang telah disebutkan sebelumnya. Selanjutnya, kalimat وهم على فرش النوم diterjemahkan dengan mereka berada di tempat tidur. Huruf 'alā yang menjadi kata sambung penting dalam unsur kalimat tersebut tidak diterjemahkan. Terjemahan yang cocok untuk kalimat tersebut sebaiknya adalah merasa bahwa diri mereka terlibat dalam perang dunia, (padahal) mereka berada di tempat tidur.

Kalimat غنموا قُرحة المعدةِ، وضَعطَ الدم و السكَّريَّ diterjemahkan dengan pemilihan diksi yang kurang tepat yaitu "memahami sakit perut". Arti tersebut juga tidak memiliki struktur kalimat yang jelas. Arti yang lebih tepat adalah "mereka memperoleh luka di pencernaan". Huruf "wau" diatas adalah huruf tambahan yang tidak perlu untuk diterjemahkan. Hal ini merupakan suatu strategi penerjemahan yang dinamakan pengurangan. Pengurangan ini bukanlah suatu pilihan akan tetapi adalah 
Hidayatul Khoiriyah: Kualitas Hasil Terjemahan Google Translate Dari Bahasa Arab ke Bahasa Indonesia

suatu keharusan konteks bacaan. ${ }^{2}$ Terjemahan yang lebih tepat adalah "tekanan darah tinggi dan penyakit gula (diabetes)".

Secara keseluruhan kalimat di atas tidak memiliki struktur yang jelas. Struktur kalimat yang benar dibentuk berdasarkan unsur subjek, predikat (disertai objek jika predikat menggunakan kata kerja transitif), pelengkap dan keterangan. Akan tetapi ejaan yang benar juga ditunjukkan oleh data diatas dengan penggunaan huruf kapital di awal sebuah kalimat.

Maka arti secara keseluruhan kalimat di atas adalah sekelompok orang merasa bahwa diri mereka terlibat dalam perang dunia, padahal mereka berada di atas tempat tidur. Tatkala perang usai yang mereka peroleh adalah luka di pencernaan mereka, tekanan darah tinggi dan penyakit gula (diabetes).

$$
\begin{aligned}
& \text { و نصيحتي لك أن لا تحمل الكرة الأرضية على رأسك. دع الأحداث على الأرض ولا تضعها } \\
& \text { في أمعائك، إن بعض عنده قلب كالإسفنجة يتشب الشائعات و الأراجيف، ينزعج للتوافه، يهتز } \\
& \text { للواردات، يضطرب لكل شيء، و هذا القلب كفيل أن بحطم صاحبه، وأن ههدم كيان حامله. }
\end{aligned}
$$

Saran saya adalah agar Anda tidak memegang bola dunia di kepala Anda. Tinggalkan kejadian di tanah dan jangan taruh di perutmu. Beberapa orang memiliki hati seperti spons yang menyerap desas-desus dan roti, mengganggu hal-hal sepele, menggetarkan impor, mengganggu segalanya, dan hati ini cukup untuk menghancurkan pemiliknya dan menghancurkan entitas pengangkutnya.

Terjemahan kalimat pertama dalam paragraf di atas melenceng أن لا تحمل jauh dari arti dan gagasan penulis sebenarnya. Kalimat diartikan google translate dengan mengabaikan bahwa kalimat tersebut adalah kalimat yang didahului oleh lā nāhiyah yang bermakna larangan "jangan". Google translate menerjemahkan dengan arti "tidak memegang" dengan asumsi bahwa huruf lā adalah lā nāfi yang berarti meniadakan. Google menganggap seakan-akan bahwa kata-kata tersebut merupakan keterangan sifat dalam objek. Terjemahan yang benar adalah

2 Munip, Strategi dan Kiat Menêrjemahkan Teks Bahasa Arab Ke Dalam Bahasa Indonesia, h. 124. 
Hidayatul Khoiriyah: Kualitas Hasil Terjemahan Google Translate Dari Bahasa Arab ke Bahasa Indonesia

"Saran saya kepada anda jangan meletakkan bola dunia di kepala anda" bukan "anda yang tidak memegang bola dunia di kepala anda". Google translate tampaknya tidak konsisten dalam mengartikan kalimat دع الأحداث على الأرض ولا berdasarkan data yang ada. Selanjutnya terjemahan diterjemahkan dengan arti "Tinggalkan kejadian $\underline{\text { di tanah }}$ dan jangan taruh di perutmu"adalah terjemahan yang menggunakan pemilihan diksi yang kurang tepat. Terjemahan kata "di tanah" dan "perut" tidak sesuai dengan konteks kalimat yang ada, walaupun terjemahan tersebut bisa dibenarkan dalam tataran arti kosakata. Terjemahan "tinggalkan kejadian di tanah" lebih bagus bila diterjemahkan dengan "biarkan kejadian-kejadian itu terjadi dan jangan menyimpannya di dalam pikiran anda". Kalimat "taruh" dan "perut" terasa lebih cocok bila diganti dengan kalimat "menyimpan" dan "pikiran".

Pembuangan arti kata إن oleh google sudah tepat penggunaannya إن بعض عنده untuk memperoleh terjemahan yang bagus dalam kalimat قلب كالإسفنجة يتشرب الشائعات و الأراجيف memiliki hati seperti spons yang menyerap rumor dan roti". Adapun kalimat yang berada setelah huruf " $k a f$ " merupakan terjemahan yang kacau karena diartikan dengan kalimat yang tidak dapat dipahami yaitu "seperti spons yang menyerap rumor dan roti". Terjemahan yang lebih tepat adalah "beberapa orang yang memiliki hati seperti bunga karang akan menyerap semua isu dan kasak kusuk". Selanjutnya kalimat ينزعج juga tidak bisa diartikan dengan tepat bahkan salah oleh google dengan terjemahan "mengganggu hal-hal sepele". Terjemahan kalimat tersebut adalah "terkejut oleh masalah-masalah kecil". Kemudian يضطرب diartikan dengan "menggangu segalanya", diksi yang lebih tepat adalah "terguncang oleh peristiwa-peristiwa yang terjadi". Secara generik "syai" biasa diterjemahkan dengan "hal" atau "sesuatu", akan tetapi konteks diatas kurang tepat dan kurang bisa menerima 
Hidayatul Khoiriyah: Kualitas Hasil Terjemahan Google Translate Dari Bahasa Arab ke Bahasa Indonesia

و هذا القلب كفيل أن penerjemahan "syai" dengan kalimat tersebut. Kalimat diterjemahkan oleh google seperti berikut "dan hati ini cukup untuk menghancurkan pemiliknya dan menghancurkan entitas pengangkutnya". Susunan terjemahan tersebut kurang sesuai dengan kaidah yang berlaku di Indonesia. Arti dua kalimat setelah "hati ini" merupakan terjemahan yang terlalu boros dan tidak hemat (walaupun google translate salah dalam mengartikannya) karena mempunyai arti yang hampir sama. Akan lebih baik jika terjemahan tersebut disederhanakan dengan tidak menyalahi terjemahan aslinya seperti "hati ini sangat potensial menjadi awal kehancuran". Hal ini sesuai dengan ciri-ciri kalimat efektif tentang kehematan. Untuk menjamin kehematan kalimat, setiap unsur kalimat harus berfungsi dengan baik, dan unsur yang tidak mendukung makna kalimat harus dihindarkan.

Jadi, keseluruhan paragraf kedua diartikan Saran saya untuk Anda: jangan meletakkan bola dunia di atas kepala. Biarkan semua peristiwa itu terjadi, dan jangan disimpan di dalam pikiran. Orang yang memiliki hati seperti bunga karang akan menyerap semua isu dan desas desus, termakan oleh masalah-masalah kecil, dan mudah terguncang karena peristiwa-peristiwa yang terjadi. Hati seperti ini sangat potensial menjadi awal kehancuran.

\section{E. Peranan Mesin Terjemah Google Translate Dalam Proses Pembelajaran Bahasa Arab}

Adanya mesin terjemah saat ini diharapkan akan mampu memberikan dampak positif bagi proses pembelajaran bahasa yang dilakukan di sekolah-sekolah maupun kampus-kampus. Sebagaimana yang telah diketahui bahwasanya terdapat empat keterampilan dalam pembelajaran bahasa yaitu keterampilan mendengar (mahärah alistimā'), keterampilan berbicara (mahārah al-kalām), keterampilan membaca (mahārah al-qirā'ah), dan keterampilan menulis (mahārah al-kitābah). Setiap keterampilan tersebut tentunya sangat penting bagi proses pemahaman suatu bahasa asing. Salah satu hal penting dalam 
Hidayatul Khoiriyah: Kualitas Hasil Terjemahan Google Translate Dari Bahasa Arab ke Bahasa Indonesia

pembelajaran bahasa adalah suatu pemhaman mengenai arti serta makna kosa kata bahasa yang sedang dipelajari.

Mempunyai banyak perbendaharaan kosa kata akan memudahkan pembelajar dalam menguasai bahasa. Salah satu cara untuk mengenai kosa kata adalah melalui kamus, baik berupa kamus cetak maupun kamus online. Seiring berkembangnya era digital saat ini mayoritas pembelajar bahasa Arab di Indonesia menggunakan kamus online dan mesin penerjemah (google translate).

Melihat hasil analisis ketepatan kosa kata dan istilah mesin terjemah (google translate) dari bahasa Arab ke bahasa Indonesia yang sangat baik sekitar 70\%, maka teknologi ini setidaknya dapat menjadi pertimbangan bagi guru dalam melaksanakan proses pembelajaran bahasa. Penggunaan google translate dalam penerjemahan kosa kata bahasa Arab ke bahasa Indonesia dalam suatu proses pembelajaran di sekolah maupun kampus hendaknya harus disertai dengan pengawasan dari guru. Google translate setidaknya akan cukup membantu bagi proses pembelajaran bahasa Arab khususnya bagi pembelajar dalam upaya pemerolehan arti atau makna kosa kata. Proses penerjemahan yang cepat adalah satu keunggulan yang ditawarkan oleh google translate dibandingkan dengan menggunakan kamus cetak. Bagi pembelajar dewasa tentunya hal ini menjadi pertimbangan yang penting.

Fasilitas internet yang cukup mudah didapatkan baik bagi guru maupun siswa akan membawa kemudahan dalam proses pembelajaran bahasa tentunya. Seorang guru akan dengan mudah dan cepat mencari bahan pengajaran dari internet yang dapat disesuaikan dengan usia siswa. Sedangkan bagi siswa, mereka akan dapat bereksplorasi dengan tugas-tugas yang diberikan oleh guru melalui media internet. Dengan demikian, dapat diharapkan akan terjadi komunikasi dua arah antara siswa dengan guru sehingga suasana kelas akan semakin hidup, aktif, dan tidak membosankan.

Guna ikut berperan serta dalam proses peningkatan kualitas mesin terjemah (google translate) hendaknya guru bersama-sama dengan siswa memberikan saran berupa suatu terjemahan yang 
Hidayatul Khoiriyah: Kualitas Hasil Terjemahan Google Translate Dari Bahasa Arab ke Bahasa Indonesia

dianggap lebih baik dan lebih cocok dibandingkan dengan terjemahan mesin (google translate) mengenai suatu kosa kata, istilah maupun teks bahasa sumber (bahasa Arab) ke dalam bahasa sasaran (bahasa Indonesia). Kegiatan ini secara tidak langsung ikut berperan aktif dalam peningkatan kualitas mesin terjemahan (google translate). Karena saran terjemahan yang diberikan oleh pengguna (user) dengan terjadwal akan dijadikan pertimbangan teknisi google dalam peningkatan kualitas produknya.

Google translate merupakan mesin terjemah yang bersifat "open minded" maksudnya adalah google translate memberikan ruang khusus bagi para pengguna (user) untuk memberikan penilaian terhadap terjemahan yang dihasilkan oleh google sekaligus memberikan saransaran yang lebih baik dalam terjemahannya. Semakin banyak pengguna (user) yang aktif dalam pemberian saran terjemahan ini, diharapkan semakin baik pula kualitas google translate ke depan. Peran guru serta siswa diharapkan mampu untuk menjadi penyumbang besar dalam perbaikan mesin terjemahan ini.

\section{SIMPULAN}

Berdasarkan pembahasan yang telah disampaikan di atas, penggunaan google translate sesungguhnya memberi banyak kemudahan pada seluruh penggunanya, apalagi alasan ekonomis dan praktis semakin menjadikan layanan ini menjadi penolong instan dalam menyelesaikan masalah terkait penerjemahan.

Namun penggunaan layanan ini juga harus disertai dengan kesadaran akan kelemahan mesin penerjemah secara umum. Apalagi penerjemahan bahasa Arab ke dalam bahasa Indonesia yang memang keduanya mempunyai perbedaan kaidah gramatikal yang sangat mendasar. Google translate tidak mampu untuk menganalisa sebuah gramatika dan konteks kalimat bacaan dari bahasa sumber (bahasa Arab) ke bahasa sasaran (bahasa Indonesia), sehingga tidak mampu untuk menerjemahkan dengan baik dan sesuai dengan gramatika bahasa sasaran. Kesalahan yang terdapat dalam terjemahan google translate mencakup beberapa aspek linguistik yaitu aspek morfologis, 
Hidayatul Khoiriyah: Kualitas Hasil Terjemahan Google Translate Dari Bahasa Arab ke Bahasa Indonesia

sintaksis, dan semantik. Google translate juga tidak memiliki suatu jenis terjemahan yang jelas dan konsisten.

\section{DAFTAR PUSTAKA}

Al-Farisi, M. Zaka. Pedoman Penerjemahan Arab Indonesia. Bandung: Remaja Rosdakarya, 2011.

Al-Yassu'i, Fr. Louis Ma'luf. Al-Munjid fì al-Lughah wa al-A'lām. Beirut: Dār AlMasyriq, 1996.

Arifatun, Novia. "Kesalahan Penerjemahan Teks Bahasa Indonesia Ke Bahasa Arab Melalui Google Translate (Studi Analisis Sintaksis)," 2012,

Astari, Rika, Syamsul Hadi, Soepomo Poedjosoedarmo, dan Suhandano Suhandano. "Pengaruh Budaya Terhadap Istilah Sains dan Teknologi dalam Bahasa Arab." Adabiyyāt: Jurnal Bahasa dan Sastra 13, no. 2 (31 Desember 2014)

Hasan, Hasan, Penerjemahan Arab-Indonesia Antara Bahasa dan Budaya Banjarbaru: Atap Buku, 2017

Husin, Husin, dan Hatmiati Hatmiati. "Budaya Dalam Penerjemahan Bahasa." Al Mi'yar: Jurnal Ilmiah Pembelajaran Bahasa Arab dan Kebahasaaraban 1, no. 2 (14 Oktober 2018) https://doi.org/10.35931/am.v1i2.43.

Mufid, Nur. Buku Pintar Menerjemahkan Arab Indonesia. Surabaya: Pustaka Progressif, 2007.

Munip, Abdul. Strategi dan Kiat Menerjemahkan Teks Bahasa Arab Ke Dalam Bahasa Indonesia. Yogyakarta: Bidang Akademik UIN Sunan Kalijaga, 2008.

Nur, Syahabudin. "Problematika Linguistik (Ilmu Al-Lughah) Dalam Penerjemahan Bahasa Arab Ke Bahasa Indonesia." Al Qalam: Jurnal Ilmiah Keagamaan dan Kemasyarakatan, 18 Oktober 2018. DOI: https://doi.org/10.35931/aq.v0i0.52

Nuraini dan Sumardiono, Nababan. Penilaian Model Kualitas Terjemahan. Surakarta: Universitas Sebelas Maret, 2012.

Pujiati, Tri. "Pemanfaatan Google Translate Dalam Penerjemahan Teks Bahasa Inggris Ke Dalam Bahasa Indonesia (Aplikasi Linguistik Terapan Bidang Penerjemahan)," 2017.

Ruskhan, Abdul Gaffar. Bahasa Arab dalam Bahasa Indonesia: Kajian tentang Pemungutan Bahasa. Jakarta: Gramedia Widiasarana Indonesia, 2007.

Sa'diyah, Zaimatus. "Tipologi Kesalahan Kebahasaan Dan Keakuratan Hasil Terjemahan Google Translate Teks Bahasa Indonesia Ke Dalam Bahasa Arab" 6, no. 2 (2014) 
Hidayatul Khoiriyah: Kualitas Hasil Terjemahan Google Translate Dari Bahasa Arab ke Bahasa Indonesia

Setiawan, Teguh. "Korpus Dalam Kajian Penerjemahan," 2017, Yusuf, Suhendra. Teori Terjemah Pengantar ke Arah Pendekatan Linguistik dan Sosiolinguistik. Bandung: Mandar Maju, 1994. 